\title{
Senmodernitetens universitetsstuderende?
}

\author{
Jens Peter Thomsen, ph.d.-stipendiat, Institut for Psykologi og Uddannelsesforskning, Roskilde
}

\section{Universitetscenter}

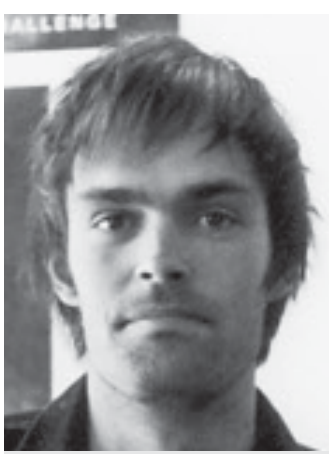

Jens Peter Thomsen er cand. scient.soc. og ph.d.-stipendiat ved Institut for Psykologi og Uddannelsesforskning, Roskilde Universitetscenter. Har tidligere været ansat som studievejleder ved RUC's centrale studievejledning og har fra 2002 undervist og vejledt på kandidatuddannelsen i Pædagogik.

Han interesserer sig for uddannelsessociologiske og uddannelsespolitiske problemstillinger, specielt i forhold til de videregående uddannelser, og i hans ph.d.-projekt undersøger han sammenhængene mellem unges valg af universitetsuddannelse, uddannelseskulturer og de studerendes oprindelsesklasse. En kort introduktion til ph.d.-projektets problemfelt kan læses i Samfundsøkonomen, nr. 5, 2005.

\section{Reviewet artikel}

I denne artikel vil jeg, på baggrund af et igangverende ph.d.projekt, soge at nuancere billedet af nutidens unge universitetsstuderende. Med udgangspunkt $i$ empiriske studier på tre universitetsuddannelser vil jeg diskutere senmoderne forståelser af de unge, og jeg vil plodere for at reflektere grundigt over hvilke antagelser man som forsker og underviser har om de unge studerende - det har nemlig konsekvenser for den padagogiske praksis.

\section{Indledning}

Temaet for dette nummer af Dansk Universitetspædagogisk Tidsskrift, At gore de studerende til studerende - senmodernitetens universitetspedagogik, lægger op til, at noget særligt senmoderne kendetegner samfundet (og dermed de studerende), og at dette følgelig sætter nogle bestemte præmisser for universitetspædagogikken. Denne artikel tager imidlertid sit begyndelsespunkt ved at supplere med et spørgsmålstegn efter temaoverskriften. Hvad taler vi om, når vi taler om senmodernitet? Er det et vilkår, en forståelsesramme, et perspektiv på unge studerende og universitetspædagogik eller noget helt fjerde?
Det generelle billede af universitetsstuderende i dag er tilsyneladende præget af visse modsætningsfyldtheder - på den ene side ses de unges uddannelsesvalg som præget af en mere generel individualiseringstendens, hvor valget af uddannelse er et identitetsprojekt præget af en høj grad af selvrefleksivitet. På den anden side er der en række forudsigeligheder i unges uddannelsesvalg, der i praksis er præget af normalitet og pragmatiske overvejelser om fremtid og job.

I denne artikel vil jeg forsøge at bidrage til en nuancering af billedet af unge universitetsstuderende med udgangspunkt $i$ et igangværende ph.d.-projekt om unges valg af universitetsuddannelse, deres sociale baggrund og den kulturelle praksis på tre udvalgte universitetsuddannelser. I artiklen vil jeg behandle de studerendes sociale karakteristika og anlægge et kulturteoretisk perspektiv på deres studiekulturelle praksis, specielt $\mathrm{i}$ forhold til det der har været en udbredt forståelsesfigur i forhold til unge generelt og unge studerende specifikt de sidste mange år; forestillingen om det senmoderne som nutidigt subjektivt oplevet vilkår. Det betyder i denne sammenhæng at forstå unge studerende som senmoderne studerende kendetegnet ved at være udpræget selvrefleksive og selvkonfronterende i forhold til deres livsbiografi og dermed også i forhold til deres uddannelsesvalg. Artiklen slutter med en opfordring til grundigt at overveje hvilke forestillinger om de studerende, man planlæegger sin undervisning ud fra.

\section{De senmoderne studerende}

Det senmoderne, eller det refleksivt moderne, repræsenterer en form for radikaliseret modernitet kendetegnet ved, ikke bare at have brudt med traditioner og faste forhold, men ved at individet nu også bliver konfronteret med sig selv. Selvet bliver, med Giddens' ord, et refleksivt projekt (Giddens 1991, s. 32), eller som Beck skriver: »[...] the standard biography becomes a chosen biography, a 'do-it-yourself biography' $[. .$.$] « (Beck$ 1994, s.15). For Ziehe er denne proces præget af en hidtil uset grad af kulturel frisættelse (fra normer, værdier, traditioner, mv.) på det subjektivt oplevede niveau. Identiteten er udskiftelig, og subjektet er frit men også 
tvunget til at skrive sin egen biografi; til at konstruere sin egen livshistorie. For Ziehe leder denne subjektivering til ambivalenser og stress, $i$ forhold til hvordan subjektet skal begrunde sine valg og beslutninger, når alle traditionelle fikspunkter og henvisningsinstanser er borteroderet, ligesom det åbner op for at identitetsdannelsen følgelig kan 'koloniseres' af medier, markedsprocesser, mv. (Ziehe 1989; Ziehe \& Stubenrauch 1984).

Ziehe har haft stor indflydelse på den måde, hvormed spørgsmål om unge og uddannelse er blevet forstået $i$ dansk uddannelsesforskning. Man kan måske tale om en særlig 'dansk' reception af Ziehe, hvor der har været en tendens til at fokusere på unge som spændings- og forandringssøgende individualister, der kontinuerligt konstruerer og rekonstruerer deres identitet. Unge for hvem uddannelse vælges efter dens mulighed for at give dem en identitet og for at være personligt udviklende (Simonsen 2000; Illeris, m.fl. 2002; Simonsen \& Ulriksen 1998). Når jeg herefter diskuterer senmodernitetens unge studerende, tænker jeg således primært på den tankefigur, der ser unge som værende på kontinuerligt identitetsarbejde og som primært drives af den personlige interesse som uddannelses- og læringsbegrundelse. Samtidig skal det understreges, at vi her, som tidligere nævnt, bevæger os på det subjektivt oplevede niveau langt de fleste, der taler ud fra en senmoderne position, understreger, at udvidelsen i subjektets mulighedshorisont netop er oplevet - den er ikke blevet medfulgt af en tilsvarende sociokulturel og socioøkonomisk frisættelse (se eksempelvis Simonsen 1999).

Spørgsmålet, jeg med udgangspunkt i interview og observationer fra tre universitetsuddannelser vil efterforske, er nu følgende: Er senmodernitetens kendetegn et generelt træk ved de universitetsstuderende? Finder vi i praksis subjektiveringsprocesser og kulturelle karak- teristika blandt de universitetsstuderende, der empirisk kan understøtte denne antagelse? I første omgang er det dog nødvendigt kort at skitsere de studerendes sociale profil for at have en velfunderet baggrund for at forstå den studiekulturelle praksis, der kendetegner de tre uddannelser.

\section{Danske universitetsstuderendes sociale karakteristika}

Det er måske velkendt, at der blandt danske universitetsstuderende er en overvægt af kvinder, at der er en underrepræsentation af etniske minoriteter, og at der er en voldsom overrepræsentation af studerende, hvis forældre selv har en højere uddannelse. Faktisk er rekrutteringen til universitetsuddannelser næsten ligeså skæv i dag som for tredive år siden - på trods af en bred politisk konsensus om at sikre alle unge lige muligheder for uddannelse. Mindre velkendt er det måske, at de universitetsstuderende selv på ingen måde er en social homogen gruppe. Faktisk er der endog meget store forskelle i de universitetsstuderendes sociale baggrund, alt efter hvilken universitetsuddannelse og universitetsinstitution vi betragter. Jeg har beskrevet dette lidt mere udførligt andetsteds (Thomsen 2005) og vil her blot gengive nogle eksempler på de uligheder, der er tale om.

Den relative uddannelseschance udtrykker, hvor stor eller lille ens chance er for at læse en given uddannelse, hvis man er barn af forældre med en lang videregående uddannelse $\mathrm{i}$ forhold til, hvis man er barn af uuddannede forældre. Den er altså et kondenseret udtryk for den sociale skævrekruttering på de lange videregående uddannelser. Generelt er sandsynligheden for, at børn af forældre med en lang videregående uddannelse selv læser en lang videregående uddannelse

\begin{tabular}{|l|c|}
\hline Universitetsuddannelser & Uddannelseschancer \\
\hline Læge - Københavns Universitet & 21 \\
Litteraturvidenskab - Københavns Universitet & 17 \\
Statskundskab - Københavns Universitet & 17 \\
Kunstakademiets Arkitektskole & 14 \\
Civilingeniør - Danmarks Tekniske Universitet & 13 \\
Jura - Københavns Universitet & 9 \\
Erhvervssproglig bachelor - Copenhagen Business School & 4 \\
Civilingeniør, bygge/anlæg - Ålborg Universitet & 3 \\
Danmarks Pædagogiske Universitet & 2 \\
\hline
\end{tabular}

Anm: Uddannelseschancer er udregnet som andel af forældre med en lang videregående uddannelse over andel af forældregeneration med en lang videregående uddannelse, divideret med andel af forældre med grundskoleuddannelse over andel af forældregeneration med grundskoleuddannelse.

Kilde: Egne beregninger ud fra registerdata og tal fra Statistikbanken (Danmarks Statistik). 
syv gange større, end sandsynligheden for at børn med ufaglærte forældre læser en lang videregående uddannelse. En anden måde at sige det på er, at det udtrykker chanceuligheden mellem børn af højtuddannede og lavtuddannede forældre. Men der er som nævnt store forskelle på uddannelseschancerne de enkelte universitetsuddannelser i Danmark imellem. Tabel 1 giver en række eksempler på disse.

Som tabel 1 illustrerer, dækker en generel social ulighed i rekrutteringen til universiteterne over store forskelle internt på uddannelserne. Når vi har at gøre med studerende med meget forskellige sociale karakteristika, kan der være grund til at antage, at de studerendes sociale og kulturelle praksis såvel som deres subjektive erfaringsmønstre også er forskellige. Her har en række forskere undersøgt sammenhængen mellem social klasse og de unges uddannelsesstrategier. Bourdieu har skrevet om uddannelseseliten og dens strategier (Bourdieu 1996). Den engelske uddannelsessociolog Basil Bernstein har skrevet om de 'gamle' og 'ny' middelklasser, og om hvordan det personlighedsudviklende er noget, der hører den 'ny' middelklasses uddannelsesstrategier til (Bernstein 1997; Bernstein 1990), ligesom Mikael Palme i Sverige har understreget personlighedsudviklingen som særlig strategi i uddannelsessystemet indenfor visse sociale klasser (Palme 1990). Nyere engelsk forskning differentierer mellem forskellige middelklasser og tilsvarende forskellige strategier i forhold til valg af videregående uddannelse (Ball 2003; Power 2003; Reay, m.fl. 2005). Fælles for de nævnte forskere er, at de anlægger et perspektiv, der fokuserer på den sociale interaktion $\mathrm{i}$ uddannelse og familie, og på hvordan og hvorfor den varierer systematisk med social klasse.

I forhold til spørgsmålet om de senmoderne studerende bliver det her interessant, hvorvidt man i mit materiale finder variationer på tværs af universitetsuddannelserne:Vil uddannelser med forskellige sociale karakteristika også vise forskelle i de måder, de studerende interagerer med hinanden på, og i den måde de fortæller deres uddannelsesvalg frem på? Dette vil jeg i det følgende diskutere med udgangspunkt i empiri fra mit ph.d.-projekt, og jeg vil forsøge at rette blikket mod nogle af de områder af den kulturelle praksis, der kan siges at være relevante i forhold til spørgsmålet om de senmoderne universitetsstuderende.

\section{Forskningsdesign og metode}

Med kulturel praksis hentyder jeg til den hverdagslige sociale samhandlen på uddannelserne, som de studerende er fælles om, og som de er fælles om at tillægge betydning. Dette ligger i forlængelse af en britisk kultursociologisk forståelse af kultur som 'a whole way of life', der ofte bruger etnografiske tilgange trækkende på sociologi og antropologi (Johnson 1986). At tilhøre den samme kultur vil derfor sige, med den engelske kultur- forsker Stuart Halls ord, at tolke verden betydningsfuldt i gensidigt forståelige og anerkendte måder (Hall 1997, s. 2). Mere konkret kan man i denne sammenhæng tale om en studiekulturel praksis, forstået som den praksis de studerende er 'stakeholders' i; som det de studerende er fælles om at betragte og anerkende som arena for udfoldelse i relation til deres uddannelse. En kulturel praksis er altid betinget af de sociale omstændigheder, den udfolder sig i - hvorfor det i dette tilfælde også vil være væsentligt at vide noget om de studerendes sociale baggrund. Min forskningsinteresse er altså fokuseret i forhold til det, der konstituerer en kulturel praksis som en afgrænset social interaktion og dens forhold til den bredere sociale klasse. ${ }^{1}$ Samtidig indebærer dette også, at optikken rettes mod den 'samlende' kulturelle praksis blandt de studerende (og på forskellene uddannelserne imellem) og ikke på differentieringer blandt de studerende på de enkelte uddannelser.

I forlængelse af interessen for den kulturelle praksis er det metodiske udgangspunkt for de kvalitative undersøgelser (observationer og interviews) etnografisk (Hammersley \& Atkinson 1995; Coffey \& Atkinson 1996). ${ }^{2}$ Der er brugt deltagende observation, hvor jeg har observeret bagerst i lektionslokalet og spurgt og interageret med de studerende udenfor lektionerne. Ambitionen har været at søge en empatisk tilgang til studielivet - at se det i 'studenterhøjde' (og følgelig har jeg afgrænset mig fra $\mathrm{fx}$ institutionernes historie og underviserne). Det, der har ledt blikket i observationerne, har i første omgang været et bredt perspektiv på hverdagslivet på studiet (i forlængelse af kulturperspektivet): på interaktionsformer, sociale ritualer, interaktion med underviserne, anerkendelsesmekanismer, dominerende praksisser, mv. Denne indledende afsøgning har langsomt udstykket nogle tematikker, der er blevet forfulgt $\mathrm{i}$ interviewene sammen med en række baggrunds- og handlingsspørgsmål om eksempelvis opvækst, uddannelseshistorik, fritidsbeskæftigelse, mv. Interviewene er foretaget som semistrukturerede interview ud fra samme etnografiske tilgang: De bruges primært til at fokusere på den enkelte studerendes fortælling om, hvordan det er at være en del af studielivet på den specifikke uddannelse, mere end på den enkeltes identitetskonstruktion eller subjektive tackling af studielivet.

Begrebet kulturel praksis er en konstruktion i slutningen af analyseprocessen, hvis begyndelse har været kodninger af observationer og interview, som derefter er samlet $i$ temaer og analytiske kategorier. Denne empiri, sammen med registerdata om de studerendes sociale baggrund, danner grundlag for selve ph.d.-projektet, og det skal understreges, at denne artikels omfang kun tillader nogle få eksempler fra udvalgte temaer fra afhandlingens analyse af de forskellige kulturelle praktikker på uddannelserne. I denne artikel har jeg også valgt at fokusere på interviewene, da det er her det er muligt at efterspore beskrivelser af, til hvilken grad senmoderniteten 'opleves'. De temaer, der behandles her, orienterer 
sig omkring, hvordan de studerende oplever overvejelser om uddannelsesvalg, forældrenes indflydelse, studiets 'fylde' og overvejelser om fremtidigt job - temaer, jeg ser som relevante $i$ forhold til en senmodernitetsproblematik, da det er her man kunne forvente at iagttage beskrivelser, der knytter sig til specifikt senmoderne prægede processer (i forhold til spørgsmål vedrørende uddannelse som identitetsprojekt, frisathed, refleksivitet og biografisk konstruktion).

Udgangspunktet for udvælgelsen af de tre uddannelser til de kvalitative undersøgelser er bearbejdet registerdata fra Danmarks Statistik. På den ene side er der valgt uddannelser med forskellig sociale profil (som tabel 1 viser, er de to KU-uddannelser præget af en meget skæv social rekruttering, mens det i langt mindre grad er tilfældet for CBS-uddannelsen), på den anden side har ønsket også været at udforske forskelligheder blandt uddannelser med samme sociale profil. Det har desuden været en prioritet, at uddannelserne af praktiske grunde lå $\mathrm{i}$ københavnsområdet, og at de havde mange studerende (blandt andet af anonymitetshensyn). De valgte uddannelser er Statskundskab og Litteraturvidenskab på Københavns Universitet (KU) samt bacheloruddannelsen i Erhvervssprog og International Erhvervskommunikation på Copenhagen Business School (CBS).

Feltarbejdet har varet fra februar 2006 til december 2006. Jeg har alle steder søgt at observere over en periode på ca. 3-4 måneder - typisk 4-10 timer om ugen. På Statskundskab har jeg fulgt et hold på 30-35 studerende, på Erhvervssprog har jeg fulgt to hold med 20-25 studerende på hvert hold, og på Litteraturvidenskab har jeg fulgt et hold på 30-35 studerende (alle hold mellem 3.-5. semester). Jeg har interviewet mellem 8-10 studerende på hver uddannelse. Jeg har så vidt muligt søgt at udvælge et repræsentativt udvalg af studerende med hensyn til køn og etnicitet, og videre søgt at gøre brug af de informationer observationerne gav mig (eksempelvis at markere sig henholdsvis meget/lidt, ytre sig kritisk/ikke kritisk, studieskiftere (der kunne give kontrasterfaringer fra andre fag)). På Erhvervssprog er 7 kvinder og 2 mænd interviewet (heraf 1 mandlig etnisk minoritetsstuderende), på Litteraturvidenskab 6 kvinder og 2 mænd, og på Statskundskab 6 kvinder og 4 mænd.

Som nævnt ovenfor er uddannelserne strategisk udvalgt efter et eksemplarisk princip: det vil sige som eksempler på interaktionsprocesser, hvis dynamikker gerne skulle have en mere almen relevans. På den måde kan undersøgelsen ikke siges at være repræsentativ $i$ traditionel forstand - man kan ikke uproblematisk generalisere fra nogle studerende på et hold til alle studerende ved den samme uddannelse i Danmark. Pointen i denne sammenhæng er, at uddannelserne så at sige ikke er interessante i sig selv; de er interessante set i forhold til hinanden, og som eksempler på almene dynamikker og praksisformer på universitetsuddannelser generelt (se Hammersley \& Atkinson 1995, s. 42ff).

\section{Uddannelsesvalg blandt studerende på tre universitetsuddannelser}

De ni erhvervssprogsstuderende, jeg har interviewet, beskriver deres refleksioner over deres valg af videregående uddannelse som en kombination af en interesse for sprog og marketing og så tidlige orienteringer $i$ forhold til fremtidigt job (tre nævner interessen for sprog og marketing, én inspiration fra HHX, to hensynet til fremtidigt job, og én beskriver det som en afvejning af interesse og jobsigte - lidt 'fifty-fifty', som den studerende siger).

I hovedparten af interviewene betones det praktiske og anvendelsesorienterede ved uddannelsen - en studerende betegner sig mere som 'handelsskoletypen end universitetet', mens en anden studerende beskriver forskellen således:

"Jeg var til åbent hus på KU med filosofi og sådan noget, det var også meget interessant og det kunne jeg sagtens have valgt. Jeg kunne bare ikke se, hvad jeg skulle efter universitetet, for det var meget spandende, men jeg kunne bare ikke se, hvad jeg skulle... selvom eleverne, der laeser det, de provede virkelig at fortelle, hvad man kunne gøre, så syntes jeg stadig det var for uklart og abstrakt, og det kan jeg ikke lide. Jeg kan bedre lide at se, hvad formålet med en uddannelse er, så har jeg det også bedre med det. Jeg foler, at det jeg loser her, det kan jeg bruge til noget [...] få et godt arbejde og lon, og fà en karriere og det hele. Men hvis du laeser på Kobenhavns Universitet, så bliver du en eller anden lektor eller et eller andet. Det er det billede man fär, synes jeg. " (Salik, 23 år)

At det lige bliver den specifikke uddannelse, fortælles generelt ikke frem som noget, der er blevet lagt meget vægt på. Tre studerende fortæller det mere frem som et fravalg af uddannelser med et usikkert jobsigte. Som én udtrykker det:

"[...] jeg kunne ikke forestille mig at tage en uddannelse, altså bruge 3-5 år på noget, hvor jeg ikke bagefter ville vere sikker på at få et job, hvor jeg ikke også ville kunne tjene penge [...] en af mine bedste veninder, hun vil jo vildt gerne vere designer, og det er jo altså også bare usikkert som langt ind $i$ helvede [...] jeg kunne aldrigforestille mig at tage en uddannelse, hvor jeg ikke var sikker på at få et job. Det tager alt for lang tid." (Dorte, 20 ar)

De studerende giver næsten alle udtryk for eksplicitte overvejelser omkring fremtidigt job i virksomheder beskæftiget med kommunikation og marketing. Ingen af de interviewede studerende har fritidsaktiviteter, som de synes relaterer til deres studie, og ingen af de interviewede har studiejobs, som de ser som specielt studierelevante.

De erhvervssprogsstuderende er dem hvis forældre er kortest uddannede, og i forhold til de to andre uddannelser er det interessant, at kun én studerende 
angiver forældre som nogen, der har haft nogen form for indflydelse på uddannelsesvalget. Syv studerende siger, at deres forældre ikke har haft nogen indflydelse på deres uddannelsesvalg. Som jeg vil komme ind på senere, er billedet ganske anderledes for de studerende på de to andre uddannelser.

De interviewede litteraturvidenskabsstuderende beskriver generelt deres uddannelsesvalg som engagements- og interessedrevet. Halvdelen nævner en tidlig lyst og interesse for litteratur, for at læse og skrive og flere beskriver det som noget, der 'altid har været der'.

Seks ud af de otte interviewede studerende nævner forældrene som en indflydelse og inspiration i forhold til uddannelsesvalget, som noget 'der kommer meget hjemmefra', som én udtrykker det. En studerende starter med at fortælle, at det jo ville være oplagt at forklare det som noget 'psykologisk', som et valg der kom indefra, men fortsætter:

"Men jeg tror bare, at jeg har varet meget heldig, at jeg har begge mine forceldre, som altid begge to har lost utrolig meget, og fra meget tidligt har bare givet mig boger $i$ handen $o g$ sådan, fortalt mig om det [...]" (Nadja, 24 år)

Som en anden studerende udtrykker det:

\section{"I: Er der blevet loest mange boger $i$ din familie?}

$R: J a$, rigtig, rigtig mange. Vi har virkelig mange boger derhjemme. Og de bliver last rigtig meget.

I: Så har I også sådan diskuteret litteratur?

R: Rigtig meget, ja. Alle kulturelle emner. Så jeg har altid interesseret mig for kultur og teateret og biografen og boger. Og mange af de ting jeg ved, ved jeg derfra." (Julie, 22 år)

For de litteraturvidenskabsstuderende er den kulturelle påvirkning hjemmefra fremtrædende i de studerendes beskrivelser af overvejelser om uddannelsesvalg. Hjemmet har aktivt understøttet den enkelte studerendes udvikling, man er blevet stimuleret gennem kulturferier, ved at der er blevet diskuteret kultur og litteratur, og i det hele taget blevet læst meget i de studerendes hjem - alt sammen noget, der præparerer den enkelte studerende til uddannelsen.

De fleste af de interviewede laver ting i deres fritid, som de forbinder med deres studie (går til oplæsninger, teater, skriver, mv.), og for alle på nær én beskrives grænsen mellem studie og fritid som flydende - det er svært at skelne mellem, hvornår læse- og skriveaktiviteter er studie- eller lystbetonede. Halvdelen beskriver det som et con amore forhold til faget, som noget man brænder for. Som én siger:

»Det er forste gang, jeg har loest et sted, hvor folk faktisk interesserer sig for det, de skulle laese [...] Når folk har fri, så scetter vi os ned på X-cafeen og fär en ol eller kop kaffe eller et eller andet, og snakker videre om de ting, vi har loest eller andre boger." (Maria, 24 år)

En anden studerende beskriver faget som identitetsskabende, som et livsstilsfag:

"[...] når jeg mener livsstil, så mener jeg, at det er meget identitetsskabende at sige, at man loeser litteraturvidenskab [...] og så tror jeg også at det er et udtryk for en måde man gerne vil leve på, altså, når man volger litteraturvidenskab og loeser det, så er det jo også noget med at voere sådan lidt bohemian [...]"(Nadja, 24 år)

Det engagementsdrevne uddannelsesvalg medfølges også af tvivl om uddannelsesvalget blandt de studerende - de er sig ganske bevidste om den usikre jobfremtid, der ligger i deres uddannelsesvalg. Det er en udbredt fortælling på studiet, at det er et 'brødløst' fag, og for hovedparten af de interviewede er forestillinger om en jobfremtid enten fraværende, diffuse eller præget af en ambivalens mellem det lystbetonede studievalg og den usikre fremtid, hvor man ikke kan se, hvor det fører hen:

"Så overvejede jeg meget, hvad jeg ville. Altså dels, hvor kan jeg få et job, og hvad vil jeg, og det var så det sidste der vandt [R smågriner, JPT] (Maria, 24 arr)

„Folk er så meget $i$ tvivl tror jeg. Det er det der med, at man skal opfinde sig selv. Altså, der er overhovedet ikke noget, du kan blive. "(Julie, 22 arr)

De interviewede statskundskabsstuderende nævner næsten alle forældre, skole og gymnasiet som der, hvor deres uddannelsesinteresse kommer fra. I forhold til uddannelsesovervejelser fortæller to studerende, at deres høje karaktersnit måske gjorde, at de ikke behøvede tænke så meget over deres uddannelsesvalg, mens hovedparten beskriver valget som velreflekteret. Halvdelen af de interviewede beskriver, at mens de var sikre på at de skulle læse på universitetet, var statskundskabsuddannelsen ikke givet fra starten, men den vælges fordi det er en bred og velrenommeret uddannelse - man făr 'lidt af det hele'. Flere beskriver uddannelsesvalget som en pragmatisk afvejning af lyst, interesse, og så hvad der er fornuftigt. En studerende beskriver det på denne måde:

»S: Det var noget, vi gik og snakkede meget om i gymnasiet. At det er med at voelge det rigtige, og man skal bare valge det, man brender for og sådan noget [...] og efter de to år, hvor jeg havde pause, andrede det sig ligesom til at blive [...], at man skal sgu også valge noget, hvor man kan få et fedt arbejde. Det handler ikke bare om, at studiet skal vare fedt. Det skal også vare fedt bagefter. Jeg havde for eksempel valgt, at jeg ville lase historie, og så havde jeg sikkert syntes, at det var skide sjovt at loese. Men hvis 
jeg ikke lige umiddelbart havde lyst til at komme ud og vare arbejdslos historiker. Altså, det var så det, der gjorde, at jeg ikke valgte det. Altså, jeg synes ligesom den tendens, den andrede sig til at vare fra: Hvad brander jeg for? Til: Hvad kunne vare sindssygt fedt at arbejde med? Og så vare realistisk [...]. Det tror jeg også har varet med til at pege mit valg på det her.

I: Ja. Så det blev også sådan et lidt mere pragmatisk valg?

R:Ja, det gjorde det jo faktisk til sidst. Ja, procis. « (Kasper, 23 ar)

I forhold til de studerende på de to andre uddannelser, kan man måske sige, at interessen for uddannelsen generelt fortælles mere frem som en blanding af et instrumentelt og ikke-instrumentelt valg - af noget lyst- og interessebetonet, som på litteraturvidenskab, og af en mere fremtidsrettet orientering, som på erhvervssprog.

Halvdelen af de interviewede har, hvad de selv beskriver som studierelevante aktiviteter i deres fritid, og det er udbredt at være aktiv på studiet - syv studerende er studieaktive $\mathrm{i}$ en eller anden forstand, mens fire er politisk aktive på den ene eller anden måde. Fem har, hvad de ser som studierelevante jobs (flere nævner, at de rigtig studierelevante jobs (i ministerier, eksempelvis) først kan søges senere i studiet).

Som tilfældet også var for de litteraturvidenskabsstuderendes vedkommende, ses forældrene som en væsentlig indflydelse $\mathrm{i}$ forhold til uddannelsesvalg og -interesse; otte studerende angiver forældrene (og for to’s vedkommende også deres søskende) som nogen, der haft en betydelig indflydelse (mens to ikke mener, forældrene har betydet noget for uddannelsesvalget). I beskrivelserne drejer det sig typisk om at komme fra et samfundsinteresseret hjem, hvor der altid er blevet diskuteret meget, læst meget avis og mange bøger. Det bliver beskrevet som et selvfølgeligt valg, noget der altid har ligget i kortene. 'Min far havde sagt statskundskab fra day one', som en studerende ironisk beskriver det. Det er almindeligt at sige, at 'nu er man jo ud af en akademisk familie', hvor forældre eller søskende har været en stor indflydelse:

"[...] min søster kom til mig og sagde: 'Dig, du skal loese statskundskab'. Det sagde hun i 8. klasse [...] hvis jeg ser på mine søskendes job [...] ja, nu er min mor så blevet lidt celdre, men også hende, så er der nok sådan en embedsmandsidentitet. "(Jakob, 23 ar)

"Altså,jeg tror ret hurtigt, at jeg begyndte at lose artikler $i$ The Economist. Altså, det er også utrolig meget påvirkning fra ens forceldre og sådan noget med at se nyheder [...], og jeg tror også min far, som økonom så har man som oftest sådan ret politiske ting [...], vi kunne godt få os en snak om, altså, jeg kunne godt synes at det var utrolig spandende at hore ham, hvad handlede den kolde krig om-det synes jeg var utrolig spandende." (Martin, 24 ar)
Ingen af de studerende udtrykker stor tvivl i forhold til jobfremtiden - her er de, i modsætning til de litteraturvidenskabsstuderende, mere på linje med de erhvervssprogsstuderende, men forskellen er, at jobovervejelserne mere ligger i sikkerheden for, at der er masser af muligheder; næsten alle de studerende imødeser arbejdslivet efter studiet med ro, fordi statskundskab kan bruges til så meget, som flere udtrykker det. Når der er overvejelser om fremtidigt job, er de ofte rettet mod arbejde i ministerier, i NGO'er, eller med politik i en eller anden forstand.

\section{Diskussion}

Når man sammenligner de tre universitetsuddannelsers studerende, er der en række ting, der falder i øjnene: De erhvervssprogsstuderende specielt, men også de statskundskabsstuderende, beskriver valget af uddannelse som en blanding af interesse og hensyn til fremtidige jobmuligheder. Arbejdslivsovervejelserne tenderer til at være mere konkrete for de erhvervssprogsstuderendes vedkommende, end de er hos de statskundskabsstuderende - her ligger sikkerheden mere i en overbevisning om at have valgt en uddannelse, der er velrenommeret og bredt anvendelig. For de statskundskabsstuderendes vedkommende er livet udenfor universitetets mure også fyldt væsentlig mere op med studierelevante aktiviteter.

De litteraturvidenskabsstuderende udtrykker overvejende valg af uddannelse som udtryk for en mere personlig interesse, som et nødvendigt valg, hvor jobmulighederne fremtræder mere diffuse. Som hos de statskundskabsstuderende fylder studiet også i fritiden. Det er bemærkelsesværdigt, at de statskundskabs- og litteraturvidenskabsstuderende lægger vægt på påvirkningen fra hjemmet, mens den er næsten fraværende for de erhvervssprogsstuderendes vedkommende. Dette kan på den ene side ses som et udtryk for, at de erhvervssprogsstuderende oplever sig mindre bundet af den sociale baggrund, på den anden side vidner det også om den sociale reproduktions kulturelle dynamikker for de statskundskabs- og litteraturvidenskabsstuderendes vedkommende.

Opsummerende kan man måske her tentativt tale om en kategorisk skelnen mellem en instrumentel (uddannelse som et middel til at nå et bestemt mål) og ikke-instrumentel orientering, og i anden omgang kan man yderligere differentiere og identificere en instrumentel, en overvejende pragmatisk, og en overvejende ikke-instrumentel, eller eksistentiel, orientering. Således kan man tale om, at valget af uddannelse fortælles frem som noget eksistentielt for mange litteraturvidenskabsstuderendes vedkommende, som en mere pragmatisk afvejning mellem interesse og fremtidige jobmuligheder for de statskundskabsstuderendes vedkommende, og som et relativt instrumentelt valg for de erhvervssprogsstuderendes vedkommende - her er jobsigtet et væsentligt element. 
De forskellige tilgange, eller uddannelsesstrategier, føjer væsentlige aspekter til billedet af de senmoderne studerende. Valgene er i højere grad 'fornuftige' og forudsigelige $\mathrm{i}$ forhold til, hvad man måske kunne forvente - og hjemmet gives en stor plads i de studerendes fortællinger om uddannelsesvalg. Også det meget selvkonfronterende og den deraf følgende ambivalens og tvivl, man måske kunne forestille sig ville blive ytret generelt $\mathrm{i}$ forhold til uddannelsesvalget, træder kun tydeligt frem blandt de litteraturvidenskabsstuderende, som er dem, der passer bedst på forestillingen om den identitetsarbejdende senmoderne studerende.

De studerende er alle fælles om at udtrykke interesse som centralt for uddannelsesvalget, og i den forstand kan man tale om, at de studerende udtrykker subjektiverings- eller selvrealiseringsprocesser. Men jeg vil argumentere for, at disse interessetilkendegivelser imidlertid er så generaliserede og rutiniserede, at de fremstår som en ritualiseret del af overvejelserne omkring uddannelsesvalget. Det er først i indholdsudfyldelsen af interessetilkendegivelsen, at forskellene træder frem - og her ser vi, som nævnt ovenfor, forskellige strategier. For nogle studerende er det ikke legitimt 'bare' at ville have en uddannelse; i den kulturelle praksis værdisættes det positivt at personliggøre faget, at gøre det selvudviklende. For andre studerende, som blandt de erhvervssproglige, er det 'naturligt' at tænke uddannelsen som et middel til et fremtidigt job. Dette er eksempler på ytringer, der $i$ et kulturteoretisk perspektiv gives en anden tolkning, end hvis man forstod individernes ytringer som subjektive måder at 'tackle' det senmoderne på (kritikere af den senmoderne forståalse kan her argumentere for, at man hypostaserer; at man lægger en socialfilosofisk udviklingsteori ned over en empiri, der så at sige slet ikke er nået til teorien endnu, mens kritikere af det kulturteoretiske perspektiv vil mene, at praksisfokuseringen kun har blik for det socialt reproducerende og ikke øjne for de kollektive mentale og subjektive nybrud). Jeg har søgt at argumentere for, at det i hvert fald ogsa er nødvendigt at anlægge et kulturteoretisk perspektiv - for at komplettere billedet af de unge studerende. Hvis en bestemt gruppe unge ytrer sig $\mathrm{i}$ termer, der minder om Ziehes begreb om den kulturelle frisættelse, må det også tolkes som en bestemt gruppe individers indsocialiserede måde at ytre sig på; en måde, der i den specifikke kulturelle praksis giver såvel subjektiv betydning som social anerkendelse. Sagt på en anden måde: Hvis unge studerende betydningssætter uddannelse som en del af et konstant identitetsarbejde, kan det også ses som fællesskabskonstituerende betydningsdannelsesprocesser; som et sprogligt-kulturelt ritual, der udtrykker tilhørsforhold til andre i bestemte sociale hverdagslige situationer. Som nogle af de forskere, jeg tidligere har refereret, er inde på, kan understregningen af det personlighedsudviklende, det eksperimenterende og reflekterede valg også ses som udtryk for en bestemt social klasses kulturelle 'logik'.
De universitetsstuderende er således en meget heterogen gruppe - jeg har her givet tre eksempler, og flere studier ville yderligere føje dimensioner til billedet af danske universitetsstuderende. Dette peger samtidig mod en nuancering af et ungdomsbegreb - det er en meget forskellig gruppe unge studerende, der her analyseres, hvilket understreger, at ungdommen i dette tilfælde ikke kan forstås i bestemt ental med tilsvarende bestemte mærkater knyttet til den generaliserede ungdom. Nogle unge studerende vil måske give udtryk for, at de skal brænde for deres uddannelse, mens andre unge ser uddannelsen som vejen til jobsikkerhed.

Jeg indledte denne artikel med at konstatere nogle modsætningsfyldtheder i de studerendes uddannelsesvalg - på den ene side ses uddannelsesvalget som del af et identitetsprojekt, hvor den unge skaber sig selv gennem sit uddannelsesvalg. På den anden side, som jeg også har argumenteret for i denne artikel, er de konkrete uddannelsesvalg og overvejelser om uddannelsesvalg ofte præget af en høj grad af forudsigelighed og 'fornuftige' pragmatiske overvejelser om fremtidige jobmuligheder. Samtidig er der noget, der tyder på, at der hvor vi finder en interaktionsform og fortællinger, der kan siges at have senmoderne kendetegn, er hos unge studerende fra en bestemt socialklasse. Der er i det hele taget en stærk samvarians mellem social baggrund og uddannelsesvalg, og mellem social baggrund, uddannelsesstrategier og den kulturelle praksis på de tre uddannelser.

Jeg er ikke didaktiker og vil derfor vare mig for at komme med universitetspædagogiske anvisninger - mit ærinde har været at vise, at de studerendes socioøkonomiske omstændigheder, kulturelle praksis og individuelle erfaringer ikke viser mod fælles senmoderne kendetræk - hertil er de studerende for det første simpelthen for forskellige, og for det andet kan senmoderne ytringer også tolkes som måder at vise medlemskab til en social gruppe på. Dette understreger blot vigtigheden af, at faget og underviserne er sig bevidst om de forskellige deltagerforudsætninger, der er til stede på forskellige uddannelser. Ulriksens begreb om 'den implicitte studerende' er her nyttigt, i forhold til at identificere de forestillinger og forventninger underviserne har til de studerende. 'Den implicitte studerende' søger at indfange: "[...] hvilken slags studerende en given uddannelsessammenhæng forudsætter, og hvad det betyder for mødet mellem de konkrete studerende, lærere og studiet.«(Ulriksen 2004, s. 51). Og det er ikke:»[...] institutionens, lærernes eller de studerendes bevidste forestillinger om eller ønsker til de studerende, men dét som træder frem, når man ser på de strukturer, koder, normer og kulturer som er på færde." (Ulriksen 2004, s. 53). Derfor er det væsentligt at reflektere over, hvilke antagelser omkring ungdom og universitetsstuderende man måske mere eller mindre erkendt bærer rundt på. Måske har den ene underviser på forhånd en forventning om, at de studerende så at 
sige investerer hele deres personlighed i uddannelsen, mens en anden underviser på forhånd antager, at de studerende ikke er det mindste autoritetstro og ikke kan acceptere, at de skal beskæftige sig med noget, der ikke lige taler til dem personligt her og nu. A priori forståelser af de unge studerende risikerer at blive en selvopfyldende profeti, hvor bestemte, mere eller mindre stereotype, forhåndsantagelser om de studerende bliver bestemmende for den måde, man planlægger uddannelser og tilrettelægger undervisningen på.

Formålet med denne artikel har været at vise, hvor socialt og kulturelt forskellige studerende er. Det kan ses som et opspil til de didaktiske eksperter og som en påpegning af, at vi skal gøre os klart, hvilke eksplicitte og implicitte forestillinger vi har om de studerende. Som ofte er det selvfølgelig lettere sagt end gjort. Under alle omstændigheder er der al mulig grund til at reflektere over, hvad man gør, hvis man søger at praktisere universitetspædagogik på senmodernitetens præmisser ud fra en generaliseret forestilling om, hvad de unge studerende er for nogle.

\section{Referencer}

Ball, S. J. (2003). Class strategies and the education market. London: Routledge Falmer.

Beck, U. (1994). The Reinvention of Politics: Towards a theory of reflexive modernisation. I: Beck, U., Lash, S. \& Giddens, A. (1994). Reflexive modernization: politics, tradition and aesthetics in the modern social order. Oxford: Polity.

Bernstein, B. (1977). Class, codes and control, volume 3. London: Routledge.

Bernstein, B. (1990). Class, codes and control, volume 4. London: Routledge.

Bourdieu, P. (1987). What makes a social class? Berkeley Journal of Sociology, 32, 1-18.

Bourdieu, P. (1996). The state nobility: elite schools in the field of power. Cambridge: Polity Press.

Coffey, A. \& Atkinson, P. (1996). Making sense of qualitative data. Thousand Oaks: Sage.

Giddens, A. (1991). Modernity and self-identity. Stanford: Stanford University Press.
Hall, S. (red.). (1997). Representation: cultural representations and signifying practices. London: Sage.

Hammersley, M. \& Atkinson, P. (1995). Ethnography. London: Routledge.

Johnson, R. (1986). What is cultural studies anyway? Social Text, $16,38-80$.

Illeris, K., Katznelson, N. Simonsen, B. \& Ulriksen, L. (2002). Ungdom, identitet og uddannelse. Frederiksberg: Roskilde Universitetsforlag.

Palme, M. (1990). Personlighetsutveckling som social strategi - Den kulturella medelklassens reproduktionsstrategier. I: Rönnberg, M. \& Dahlén, P. (red.). Spelrum. Om lek, stil och flyt $i$ ungdomskulturen. Uppsala: Filmförlaget.

Power, S. (2003). Education and the middle class. Buckingham: Open University Press.

Reay, D., David, M. E. \& Ball, S. J. (2005). Degrees of choice: social class, race and gender in higher education. Stoke-on-Trent: Trentham.

Simonsen, B. (1999). Bevidsthedsmassige konsekvenser af den forsvundne viden om den sociale arvs realiteter. Arbejdspapir 23 om social arv. København: Socialforskningsinstituttet.

Simonsen, B. (2000). Jagten på selvet. Ungdomsforskning, September. Lokaliseret d. 1. april 2007 på http://www.cefu.dk/nyhedsbrev/ nr1/uddannelse_2.

Simonsen, B. \& Ulriksen, L. (1998). Universitetsstudier i krise. Frederiksberg: Roskilde Universitetsforlag.

Thomsen, J. P. (2005). Forskelle på danske universitetsuddannelser. Samfundsøkonomen, 5, 35-39.

Thomsen, J. P., Petersen, P. E., \& Lejre, T. (2003). Social arv og social klasse - studiekulturer og sociale baggrunde på lange videregående uddannelser. Dansk Padagogisk Tidsskrift, 1, 102-117.

Ulriksen, L. (2004). Den implicitte studerende. Dansk Padagogisk Tidsskrift, 3, 48-59.

Ziehe,T. (1989). Ambivalenser og mangfoldighed. København: Politisk revy.

Ziehe, T. \& Stubenrauch, H. (1984). Ny ungdom og uscedvanlige lareprocesser. København: Politisk revy.

\section{Noter}

1 For den her brugte forståelse af socialklasse, se Bourdieu (1987).

2 Til grund ligger en række metodetekniske overvejelser som pladsen ikke tillader at udfolde her (observations- og interviewtekniske overvejelser, refleksioner over forskerpositionen i feltarbejdet, metodetriangulering, $\mathrm{mv}$.). 